\title{
Consequences of the Providing Free Wi-Fi Facilities Policy to Aircraft Navigation Systems by Airlines in Indonesia in the Revolutionary Era 4.0
}

\author{
Elfrida ratnawati ${ }^{1}$ \\ \{Elfrida.r@trisakti.ac.id $\left.{ }^{1}\right\}$ \\ ${ }^{1}$ Universitas Trisakti, Jakarta, Indonesia
}

\begin{abstract}
In 2019, several airlines in Indonesia provide free Wi-Fi facilities on their aircraft. This policy is a new thing in the air transportation that makes pros and cons among the society because if it is associated with constitution number 1, 2009 concerning Aviation in particular chapter 54 letter $\mathrm{f}$ that every person in an aircraft during flight is prohibited from operating of electronic equipment due to flight navigation disturbing. In this chapter there is a discrepancy in the implementation of policies taken with the applicable constitution, and of course the airlines in making a policy will pay attention to the safety and security standards in flight. How is the policy of providing free Wi-Fi facilities in aircraft based on chapter 54 letter $f$ of constitution No. 1, 2009 concerning Aviation? How about flight safety and security from the implementation of free Wi-Fi policies by the airlines to flight operations? Those are all the main problems in this writing. This study uses normative methods, and secondary data supported by primary data by interviewing several airlines, then analyzed descriptively through a qualitative approach. The conclusion from the results of this study is that the policy of providing free Wi-Fi facilities in the aircraft does not contradict with chapter 54 letter $\mathrm{f}$ of constitution No. 1, 2009 concerning Aviation because the designation and use of radio frequency spectrum and satellite orbit are appropriate and do not interfere with each other, so that the purpose of airlines is to maintain the safety and security of passengers during flight succeeded.
\end{abstract}

Keywords: Consequences, Wi-Fi Facility Policy, Indonesian Aviation.

\section{Introduction}

At present airlines in Indonesia are competing to provide the best service for their passengers, which is contained in the vision and mission as well as the goal of becoming an airline with a digital airline, and one of them is by utilizing the information and communication technology development, which is marked by emergence of the internet as an electronic media network. This service Improvement is done by installing WiFi devices in the aircraft. Wi-Fi is a technology that utilizes electronic equipment to exchange data wirelessly (using radio waves) through a computer network, including high-speed Internet connections.

At the beginning of the 2000, the internet was considered as something new and complicated for ordinary people, but over time, in 2019, the internet is one of the most common and indispensable things for many people. Indonesian people use the internet to interact intensively in cyberspace with other person using social networking accounts. One of the habits of many people in using the internet is through a cell phone or mobile phone (HP) as an electronic telecommunications device that has the same basic capabilities as a conventional telephone, can be carried anywhere, does not need to be connected to the telephone network using a cable, and has advantages in supporting the use of the internet in applications available (smartphones). Where users are 
required to register an account that contains each person's personal data to be able to access an application that is supported by the use of the internet, for example such as Instagram, Line, Gmail, Yahoo, etc.

Beside mobile phones, there are other electronic devices that also support internet such as tablets, iPads and laptops. This makes everyone today cannot be separated or away from various electronic devices, from children to adults, their daily lives are filled with activities using electronic devices either cellphones or laptops. This habit continues when they are in transportation services, such as on a train, public transportation, bus, or even on an airplane.

Carrying out a comfortable flight is the goal of every airline so that passengers get comfort during flying, and of course it is the duty of the airlines to make it happen, the best service must be obtained by the passenger, the service is intended when the passenger has a relationship with the airline until the passenger arrives at their destination. If this continues to be maintained, passengers will automatically feel satisfied with the services of the airline company.

PT. Garuda Indonesia had first declared Wi-Fi service. In mid-January 2019 PT Citilink Indonesia followed to declare free Wi-Fi facilities on its aircraft for domestic flights from Jakarta to Denpasar. This policy is a new thing in the world of air transportation, and it is a concrete step for Indonesian airlines in improving and developing facilities and services for prospective passengers. Then this policy makes the pros and cons among the people.

On board there are restrictions on the use or activation of electronic devices and that is common in every airline. The prohibition is based on, if anyone activates an electronic device it can interfere with the navigation system, aircraft radio channels, and cause dangerous signals to the aircraft. So that passengers are doing nothing or fall asleep if they travel far enough, it turns out it only makes passengers become unproductive in undergoing the day because they can only look at the clouds or fall asleep on board. So that it was noted by one of the Indonesian airlines as an innovation to develop a facility and service for passengers.

Related to constitution number 1, 2009 concerning Aviation, in particular clause 54 letter $\mathrm{f}$ which states that everyone on an aircraft during a flight is prohibited from carrying out the operation of electronic equipment that interferes with flight navigation. Therefore there is a mismatch and unclear between the application of the policy taken and the applicable constitution, it is necessary to maintain safety and security in flight operations related to the application of the policy taken by preventing interference to the navigation signal and radio frequency when flying. Every person who uses electronic devices in the airplane and people who are capable of committing a crime by hacking the system of an electronic media network either for their own or group's interest in committing a crime which based on clause 22 of constitution number 36, 1999 concerning Telecommunications that everyone is prohibited from carrying out acts without rights, illegitimate, or manipulating access to telecommunications networks, access to telecommunications services, and access to special telecommunications networks.

The main problem in this paper is, whether the policy of providing free Wi-Fi facilities in the airplane to clause 54 letter f of constitution No. 1, 2009 is contradictory?. How is the safety and security in flying from the implementation of the free Wi-Fi policy by the airline towards the operation of the flight? And what is the impact on the flight navigation system due to the implementation of the free Wi-Fi policy by the airlines on flight operations? The type of research that will be used in this study is the type of normative legal research. The character of the research used in this paper is descriptive. Data source is a place where data from a study can be obtained. Data from the results of this study will be analyzed with a qualitative approach, so that the literature data is analyzed in depth. The qualitative approach is actually a research procedure that produces descriptive data, what is stated by respondents in writing, verbally, and real behavior (Soerjono Soekanto, Introduction to Legal Research, (Jakarta: UI-Press, 2015), p.10). Use of a qualitative approach analysis method. Conclusions are drawn using the deductive mindset method.

Based on the description above, the writer interests to discuss the policy related to the airline PT Citilink Indonesia. Examine whether the policy is in accordance with safety and security standards, whether the policy is in accordance with existing provisions or not. With this purpose of the research, the title of the study puts forward as follows: "Consequences of the Providing Free Wi-Fi Facilities Policy to Aircraft Navigation Systems by Airlines in Indonesia in the Revolutionary Era 4.0" 


\section{Discussion}

\subsection{Safety and Security in Flight}

The percentage increasing of the passengers' number from year to year requires each airline to improve safety and security in flight so that during flying passengers will feel safe and comfortable. Aviation safety is related to airport operators, air transport operators, flight navigation providers who must meet safety standards aviation consisting of: human resources, facilities and infrastructure, operational procedures standards and environmental.

One of the problems in aviation is when a frequency of aircraft accidents increases. The Ministry of Transportation of the Republic of Indonesia states that there are several factors that cause aircraft accidents, including pilot error, such as pilots are not paying attention to weather changes, mental and psychological factors of pilots and control during takeoff or grounding. The technical failure is the design of the aircraft which cannot deal with extreme weather. While bad weather is a condition that cannot be overcome during a flight. Human resources in the aspect of airplanes are officers in charge of flying airplanes and managing aircraft traffic so that they are always safe. Human resources in the air officer aspects include: pilots, flight attendants and air traffic control.

Aviation officers who fly a plane are called Pilot Flying (PF) with the duty is to assist all activities such as: talking on radio communication, reading checklists, assisting with navigation and assisting in monitoring the plane is flown by pilots called Flight Officers (FO). In the process of flying a Pilot Flying and the Flight Officer can take turn becoming a Non Flight Pilot. The Pilot Flying and Flight Officer are responsible for the flight, from take-off to grounding. Aviation officers in flying a plane in the event of an emergency occur, the Pilot Flying will keep to fly the aircraft and take over radio communication, while the Non-Flight Pilot will take the steps are written on the checklist or in the aircraft manual. Aviators or pilots on airplanes can be a potential flight accident. Aviators or Pilots are at the forefront of this process. The condition and health of a pilot who is not healthy or fit when the pilot is on duty will have an impact on the aircraft operated by the pilot. Pilots must also have a license in accordance with the Directorate General of Transportation that has been issued. Untari Christa Situmorang, "Application of Safety Aspects". Journal of Higeia, Volume 2, No.2 (2017), pp.89-95.

On Time Performance (OTP) becomes an achievement or final destination on a flight. OTP is the timeliness of performance on a flight, which aims to include a zero accident, good flight service, passenger safety and zero disease spread. Aviation in Indonesia is carried out by several airlines that have frequently flown in and out of the country. Safety and security are highly prioritized for the achievement of an airline's OTP in carrying out its duties. Untari Christa Situmorang, "Application of Safety Aspects". Journal of Higeia, Volume 2, No.2 (2017), pp.89-95.

Based on Clause 1 number 48 constitution No. 1, 2009 concerning Aviation, Aviation Safety is a condition of fulfilling safety requirements in the use of airspace, aircraft, airports, air transport, aviation navigation, and other supporting facilities and public facilities, whereas Based on clause 1 number 49 constitution No. 1, 2009 concerning Aviation, Aviation Security is a condition that provides protection to airlines from unlawful actions through the integrated use of human resources, facilities, and procedures.

In support of maintaining security in aviation, airport officers known as AVSEC (Aviation Security) will conduct security checks on an airport, every passenger who will enter the airport terminal room will be checked for safety, by checking all passenger luggage such as luggage, luggage, luggage metal goods, and passenger communication devices. All of these items will go into the X-ray machine. X-ray machine at the airport is used to detect the contents of goods in a container by using $\mathrm{x}$-rays, so that the machine can detect dangerous goods such as: objects containing gas, all forms of weapons and sharp objects, firearms and explosives, and liquid substances that are carried by passengers who want to fly. When there is dangerous passenger luggage this machine will give a signal by issuing a warning sound. After passing the $\mathrm{x}$-ray machine, the passenger will also be inspected with a metal detector, this inspection is usually carried out to examine the entire body of the passenger. Untari Christa Situmorang, "Application of Safety Aspects". Journal of Higeia, Volume 2, No.2 (2017), pp.89-95.

It aims to create security in an aircraft when the aircraft is in the air to avoid threats from safety and security and things that are not desirable. So the safety and security aspects of aviation can be realized if the flight attendants carry out procedures in accordance with the existing rules and standards and passengers are 
obliged to obey all the rules made by the airline or the airport while at the airport or while on the aircraft when takeoff, in the air and grounding.

'Safety and security is a condition to realize the plan carried out and survived in accordance with the implementation plan. The administration of special transportation can only be carried out in all fields related to this operation which has agreed to the airworthiness requirements regulated in clause 34 through clause 51 of constitution No. 1, 2009 concerning Aviation. Clause 1 number 10 of constitution No. 1, 2009 concerning Aviation states that airworthiness is an aircraft design requirement fulfilled and in safe condition for transportation. Aflah and Zulfi Chairi, "Responsibility of Air Navigation in Air Traffic Services for Flight Safety". Journal of the Ministry of Law, Volume 29, No.1 (2017), p.1-15.

According to clause 54 of constitution No. 1, 2009 concerning Aviation which regulates safety and security in aircraft during flying states as follows: Every person in the aircraft during flying is prohibited from:

a. actions that can endanger the security and safety of aviation;

b. violation of order in aviation;

c. taking or destroying aircraft equipment which could endanger safety;

d. immoral acts;

e. acts that disturb peace; or

f. the operation of electronic equipment that interferes with flight navigation.

What if these provisions are violated, they will be subject to sanctions as regulated in clause 412 of constitution Number 1, 2009 concerning Aviation.

\subsection{Comfortable on flight}

Comfortable flight while traveling is what everyone wants. Especially for passengers who spend a long time on the plane. Many things determine the comfort while on the plane, including comfortable seating, friends chatting during the trip, satisfying service to the available facilities on the plane. Of course, for passengers who choose airplanes in moving places prioritize comfort. It is not impossible during the trip that the passenger will still work, whether it is viewing the file in a cellphone or using a laptop.

Some airlines that still have shortcomings in seating space and limited facilities make it difficult for passengers if they want to rest or work, so that passengers prefer to read or sleep to get to their destination. Several factors that influence the comfort of aircraft, such as:

"Flight Comfort" (On-Line), are available at:

http://ergo.human.cornell.edu/dea3250flipbook/dea3250notes/sitting.html. (May 29, 2019)

a. Light in the cabin

b. Distance between passenger seat and seat profile.

c. Noise in the cabin.

d. Temperature in the cabin.

e. Cabin crew service.

f. Supporting facilities.

g. Storage of personal items.

One of the national airlines that have covered these factors does not stop in rejuvenating for their prospective passengers. By seeing the development of information and communication technology that is increasingly advanced and millennial generation that every day uses gadgets in their daily needs, this is used as a new innovation based on the needs of generations in the current era. This goal makes airlines in Indonesia improve their services by presenting Free Wi-Fi on the plane as a concrete action to improve the quality of airline service facilities and infrastructure.

\subsection{History of Wi-Fi in Indonesian Aircraft}

In carrying out a transportation of course we want safety and security guaranteed. Then it becomes the basis for transportation service providers in order to maintain safety and security on every trip. Comfort is also a factor that everyone is looking for in traveling. In 2013, the era was increasingly sophisticated with the advent of information technology and telecommunications. Almost every adult has electronic equipment that can be used to socialize and communicate with others who are separated by distance and time. But if you look at transportation by airplane, everyone will surely lose the opportunity to use the electronic equipment. To overcome this, PT Garuda Indonesia (Persero) Tbk as the parent company of PT Citilink Indonesia in early 2013 made the latest and first innovation in Indonesia by presenting inflight connectivity. Inflight connectivity 
or Wi-Fi On-board is installed on the latest Boeing 777-300ER aircraft and starts the first flight with the Jakarta-Jeddah route. Wi-Fi On-board on Garuda Indonesia can only be accessed and enjoyed by passengers who are in First Class and Business Class by paying a certain fee. As time goes by until 2019, Wi-Fi On-board on Garuda Indonesia is already available on Boeing 777-300 ER and Airbus A330-200 / 300 types of aircraft. (History of Wi-Fi on Aircraft"(on-line), available at: https://www.garuda-indonesia.com/en/gar/garudaindonesia-experience/in-flight/connectivity/index.page? (July 10 2019).

Seeing ancient times where technology has not yet entered the world of aviation, flight attendants are constantly reminding passengers to deactivate electronic devices which are feared to be able to disrupt flight signals and flight becomes not smooth. So passengers are required to deactivate electronic devices before taking off until grounding at the destination location. Where takeoff and grounding momentum is sensitive and pilots need more concentration to control the aircraft and avoid interference which can threaten safety and security in flight. One of the most phenomenal accidents in Indonesia was the Adam Air plane crash in 2007. In January 2007, Adam Air crashed in Majene waters, West Sulawesi. The accident occurred because the pilot and copilot did not realize the position of the plane that had been tilted down when they were repairing one of the damaged navigation equipment. (Asro Nasiri, Tohir Ismail, "Visualization of Aircraft Navigation in a Three Dimensional Format". Dasi Journal, Vol. 11 No. 1 (March 2010), pp.56-65.

April 2013, a subsidiary of PT Lion Mentari Air: Batik Air would plan to realize the installation of Wi-Fi in its fleet. Batik Air's fleet would operate with Wi-Fi and channel distribution installed in one of its aircraft. Batik Air would operate using Boeing 737 - 900 ER aircraft. Batik Air cooperates with Telkomsel as a telecommunications service provider. While the parent company, PT Lion Mentair Air, was also considering to bring Wi-Fi facilities in its fleet. PT Lion Mentari Air worked closely with Telkomsel to enable passengers to access the internet with Wi-Fi on-board.

Wi-Fi on Batik Air planes ", (On-Line), available at:

https://makassar.tribunnews.com/2013/04/10/there is - facilities - wifi - on-batik-air (16 July 2019).

Although the technology able to access Wi-Fi in aircraft has begun to exist, but its implementation must request permission from telecommunications and aviation regulators. To this day, it seems that $\mathrm{Wi}-\mathrm{Fi}$ on Lion Air has not been realized.

In November 2017, the airline Air Asia officially launched its first Wi-Fi and inflight entertainment service on low-cost airlines in Indonesia. Wi-Fi and inflight entertainment facilities on Air Asia aircraft are named ROKKI, passengers can enjoy entertainment facilities by playing games, listening to music, watching various films, reading and viewing catalogs. ROKKI has been available on a number of domestic and international flights served by Air Asia Indonesia (QZ flight code) for the cooperation and full support of Indosat Ooredoo Business as a partner provider of inflight entertainment services.

Air Asia Wi-Fi" (On-Line), available at: https://www.airasia.com/en/id/press-releases/airasia-indonesialaunch-services-Wi-Fi-in-flight-first-low-cost-in-indonesia.page (July 16, 2019)

Following its parent company, at the beginning of 2019 PT Citilink Indonesia finally legally declared free wi-fi facilities on its aircraft or called Wi-Fi on-board for domestic flights from Jakarta to Denpasar. This policy is a new thing in the world of air transportation because it is provided free of charge for all passengers. The policy is a concrete step by PT Citilink Indonesia's airline in improving and developing facilities as well as services for prospective passengers.

PT Citilink Indonesia is collaborating with PT Mahata Aero Technology to bring Wi-Fi in its fleet. PT Mahata Aero Technology cooperates with Inmarsat Aviation and Lufthansa Technic as a provider of the most advanced technology services in the aviation and satellite related world. The free Wi-Fi service can be enjoyed on the Airbus 320 aircraft belonging to the domestic route airline Citilink. Wi-Fi on-board can only be used if the aircraft is above 35,000 feet. On-board Wi-Fi technology used by Citilink airlines uses the GX Aviation System service, which is a product of Inmarsat Aviation. GX Aviation is the first and the only high-speed global wireless network service provider in the world to be sent via High-Throughput Satellites (HTS) networks. Air Navigation ", (On-line), available at http://k gather-jurnal-dunia-q.andrafarm.com/id1/29062783/Navigate Air_196460_category-world-journal-q-andrafarm.html (May 27, 2019)

\subsection{Wi-Fi Facilities and Policy Constitution No. 1, 2009 concerning Aviation}

Based on clause 1 number 46 of constitution Number 1, 2009 concerning Aviation, the meaning of flight navigation is the process of directing aircraft movements from one point to another safely and smoothly to avoid flight hazards and / or obstacles, while clause 261 of the constitution Number 1, 2009 concerning 
Aviation said that in order to realize the implementation of reliable flight navigation services for flight safety, a national flight navigation order must be established.

Flight navigation has a purpose and type in flight navigation services, where the purpose and type of flight navigation services are contained in clause 269 of constitution Number 1, 2009 concerning Aviation, the purpose of flight navigation is as follows:

a. Realization of the flight navigation service provision in accordance with applicable standards;

b. Realization of flight efficiency; and

c. The realization of an integrated and harmonious aviation navigation service network in the national, regional and international scope.

However, based on clause 270 of constitution Number 1, 2009 concerning Aviation, types of flight navigation services include:

a. Air traffic services;

b. Aeronautical telecommunication services;

c. Aeronautical Information Service

d. Aeronautical meteorological services and

e. Search and rescue information services (search and rescue).

A safety and smoothness in flight is also influenced by navigation of a flight that runs well without any technical interference is made or not made intentionally that can cause danger in flying. All aircraft are equipped with a navigation system so that the aircraft is not lost in flying. Navigation instrument panels in the aircraft cockpit provide various information for the navigation system ranging from information about the direction and height of the aircraft to the fuel status. Checking the navigation system instruments must be as thorough and strict as possible.

Air Navigation ", (On-line), available at;

http://gather-jurnal-world-q.andrafarm.com/id1/2906-2783/Navigate Air_196460_category-world-journal-qandrafarm.html (May 27, 2019)

The use of information and communication technology developments not only in the public sector, but also in the business sector. One of the business sectors that uses the development of information and communication technology is the national airline. For Indonesian airlines, the development of information and communication technology has become a necessity to support the process of improving service quality. The use of information and communication technology is needed to increase efficiency and productivity for passengers on-board.

Wi-Fi is a form and result of the development of information and communication technology that is very fast and modern at this time in Indonesia. Wi-Fi stands for Wireless Fidelity, which has the meaning of a set of standards used for Wireless Local Area Networks (WLANs). Wi-Fi is not only used to access the internet, WiFi can also be used to create a wireless network in an organization or agency. Wi-Fi technology gives users the freedom to access the internet or transfer data from meeting rooms, hotel rooms, campuses, and cafes marked with Wi-Fi Hotspot. Initially Wi-Fi was intended for use of wireless devices and Local Area Networks (LAN), but now more is used to access the internet. This allows someone with a computer with a wireless card or personal digital assistant (PDA) to connect to the internet using the nearest access point (or known as a hotspot).

Implementation of wireless networks, especially Wireless Local Area Networks (WLAN) is becoming increasingly popular because it offers broad reach. Simulations were carried out to study the characteristics of WLAN with several measured parameters. The simulation is based on a scenario to study the access point coverage with the recommended transmission power. In designing a wireless network by calculating the value of the link budget, it is known that the maximum range of the Access Point and also in placing an Access Point in an area need to consider several things including, geographical location, environmental conditions, to antenna height in order to obtain optimal performance. Wireless (wireless network) is a communication network between computers using radio frequencies, also called Wi-Fi or WLAN networks. Wireless local network or WLAN is a local area network without the use of cables where the transmission media uses radio frequency (RF), for network connections to all users in the area. This WLAN technology has many uses. Wireless LAN network standardization is IEEE 802.11 = IEEE (Institute of Electrical and Electronic Engineers) is an institution that conducts discussions, research and development of network devices which then becomes standardized for use as network devices. Prastise Titahningsih, Rakhmadhany Primananda, Sabriansyah Rizqika Akbar, "Designing Access Point Placement for Wi-Fi Networks on Passenger Trains". 
Journal of Information Technology and Computer Science Development, Vol. 2 No. 5 (May 2018), pp.20082015.

There are three components contained in a hotspot location, including the following:

a. An access point is a device that connects Wireless LAN technology with the Internet contained in a computer. The access point has the ability to serve 128 users. The area that can be reached by an access point reaches 25-1000 meters.

b. Access controller is a device that functions as an authentication tool to check whether a user is a person who has the rights or permission to access.

c. An internet link is a device that connects hotspot locations with the internet. Internet links have an internet connection capability of up to $512 \mathrm{kbps}$. The connection capability is used to serve all users in one location. The disadvantage of internet access with Wi-Fi is that access can only be done in areas as far as $100 \mathrm{~m}$ from the access point.

There are 2 (two) Wi-Fi connection methods in the aircraft that can work:

Wi-Fi On-board ", (On-Line), available at: https://www.tiket2.com/blog/this-is-how-work-wifi-on-board/ (July 24, 2019)

a. Air to Ground (ATG)

This ATG method uses two antennas mounted on the belly of the aircraft to capture signals from cellular or telecommunications towers on ground and / or capture transmitter antenna signals from cellular providers on earth. When the aircraft is at a certain height, 10,000 feet, then the antenna on the new aircraft can be able to capture Wi-Fi signals from cell towers or telecommunications on ground, through this method can produce WiFi with a speed of $3 \mathrm{Mbps}$. But the drawback of this method is that when the aircraft passes through oceanic or mountainous areas that are not reached by the transmitter provider, the signal and internet connection will also die.

\section{b. Satellite}

This method has a more stable and stronger connection because the Wi-Fi signal received by the aircraft is obtained from satellites that are in outer space. So there is no limit when passing through the ocean or mountains because the satellites are on the plane. However, to be able to receive signals from satellites, the aircraft must have 3 (three) types of antennas to capture Wi-Fi signals: Ku-Band, Ka-Band, and Ku / Ka Band. Each antenna has a speed that varies in capturing internet connections from satellites

\subsection{Wi-Fi On-board}

The use of electronic equipment in aircraft is still considered prohibited due to the constitution No. 1, 2009 concerning Aviation, especially clause 54 Letter F which states that everyone is prohibited from using electronic devices in aircraft that can interfere with flight navigation but in fact this facility is already widely used in the world International flights like Qatar Airways, Delta, to Emirates. Onboard Wi-Fi on airplanes is a facility that is now widely used as a chatter by millennial travelers.

Wi-Fi Onboard ", (On-line), available at https://phinemo.com/wifi-onboard-citilink/ (May 30, 2019).

Not permitting the use of communication devices and electronics in the aircraft during the flight would be a problem for the passengers. Passengers are not free to use smartphone and other devices that have telephone and internet signal connectivity. But lately, technology is developing very well. So everyone needs a cellphone and other electronic devices for work or socializing. The communication signal emitted by a cell phone is feared to interfere with aircraft navigation. So the cabin crew always reminds passengers to turn off their electronic devices before taking off.

Onboard Wi-Fi", (On-line), available at https://www.ticket2.com/blog/thisi-is-15-friends-providing-accesswifi-in-flight/ (31 May 2019)

This policy is motivated by the high demand for internet access on the plane during flights and also the rapid technological advances, Indonesian airlines hope that this policy can bring a major change in the air transportation system. One of them is the availability of free Wi-Fi facility with Wi-Fi On-board technology that allows passengers to still be able to activate their mobile phones and use other electronic equipment that can access the internet during flying. Free Wi-Fi services can be enjoyed on the Airbus 320 owned by Citilink airlines with domestic routes starting December 28, 2018. With this Wi-Fi On-board, passengers will get 
internet speeds up to $50 \mathrm{Mbps}$ and can connect Wi-Fi after over 30,000 feet. Citilink's On-board Wi-Fi technology uses the GX Aviation System service, which is a product of Inmarsat Aviation, where GX Aviation System is the first and only high-speed wireless service provider in the world that is sent through the HighThroughput Satellites (HTS) network.

Free Wifi Citilink ", (On-Line), available at https://travel.detik.com/travel-news/d4301617 garudaindonesiagruplfreewifidation on board? _Ga $=2.190102379$ 1134469091.15516910901210504586.1551691090 (June 10, 2019)nt are answering all question seriously. 


\subsection{Policy on Provision of Free Wi-Fi Facilities in Aircraft Based on Clause 54 Letter F of Law No. 1 of 2009 concerning Aviation}

According to H.M.N Purwosutjipto, transportation is a reciprocal agreement between the carrier and the sender, whereby the carrier is bound to carry out the transportation of goods and / or people from a certain place to a certain destination safely, while the sender is binding himself to pay the transportation fee.

H.M.N Purwosutjipto, Basic Understanding of Indonesian Commercial Law Volume 3, (Jakarta: Djambat, 1991), p.1

Clause 1 number 29 of constitution No. 1, 2009 concerning Aviation explains the meaning of the Air Transport Agreement is an agreement between the carrier and the passenger and / or sending cargo to transport passengers and / or cargo by airplane, in exchange for payment or in the form of other services. One of transportation in Indonesia is air transportation. Air transportation is currently starting to be favored by the community because it can cut travel times faster than using ground or sea transportation.

Each airline will certainly continue to improve facilities and infrastructure as well as better and more modern services for prospective passengers. One of the airlines that improves facilities and infrastructure in service and spoil their potential passengers by utilizing the development of communication and information technology and Wi-Fi Onboard is in flight as a manifestation of the vision and mission of the airline who wants to become a digital airline in Indonesia. People who now want to feel the sensation of using electronic equipment in the airplane when flying to communicate via chat, video calls, watching videos, playing games, and reading news can choose the airline that provides comfort. So, in this case the airline as a provider of air transportation services not only escorts passengers to their destination safely but also offers facilities that provide comfort for passengers who have to pay a number of costs to buy plane ticket.

In clause 1 number 1 of constitution No. 1, 2009 concerning Aviation contains the definition of aviation which states that a unified system consists of utilization of airspace, aircraft, airport, air transportation, flight navigation, safety and security, environment, and supporting facilities and other public facilities. Based on this, the writers have an opinion that the policy of providing Free Wi-Fi facilities can be an embodiment of supporting facilities and other public facilities in flight and air transport activities. Why? Because Wi-Fi OnBoard is a facility that aims to be used by the general public with the support of modern technology that can be used on the plane. So that the policy of providing Free Wi-Fi facilities can attract the interest of prospective passengers, give a more comfortable impression in the cabin and make the Citilink airline economically increase value in the implementation of air transportation nationally in Indonesia.

On-board Wi-Fi technology is certainly different from WiFi technology on ground. Wi-Fi On-board that is applied on aircraft is connected to satellites in the sky. Telecommunications towers on the ground will send signals to satellites in the sky, then satellites will catch the signal and send the signal to the aircraft. The aircraft will catch the signal aided by a tool specifically for Wi-Fi On-board technology. Whereas Wi-Fi available on ground works by receiving and sending signals through telecommunications towers located on ground. The telecommunications tower will send signals to modems that are available on ground.

H.M.N Purwosutjipto, Basic Understanding of Indonesian Commercial Law Volume 3, (Jakarta: Djambat, 1991), p.1

If the Wi-Fi On-board facility is associated with safety and security in flying that is regulated by the provisions of constitution Number 1, 2009 on Aviation clause 54 which states that: "Everyone on an airplane during flying is prohibited from:

a. actions that can endanger the security and safety of aviation;

b. violation of order in aviation;

c. taking or destroying aircraft equipment which could endanger safety;

d. immoral acts;

e. acts that disturb peace; or

f. the operation of electronic equipment which interferes with flight navigation.

According to the writer, there is a mismatch and unclear between the implementation of the policy carried out by Citilink airlines and the applicable laws and regulations. Particularly in clause 54 Letter f explicitly states that every person in an aircraft during flying is prohibited from carrying out the operation of electronic equipment that interferes with flight navigation. The purpose and goal of each passenger who is on the plane is not to activate their cellphones or laptops and other electronic devices that emit radio wave signals, because the signals generated by electronic equipment can interfere with signals from navigation and pilot communication devices with the Air Traffic Controller (ATC) tower 
(Interview with Faqih Rezka as the airline pilot company PT Citilink Indonesia, July 27, 2019).

Therefore passengers are forbidden to operate electronic equipment on board, but with this Free Wi-Fi facility it can actually make each passenger activate their electronic equipment in the form of mobile phones or laptops that have been supported by technology to access the internet so they can enjoy the Free Wi-Fi facility on the Citilink aircraft. This is certainly not as usual. In general, the flight attendants will remind passengers to deactivate electronic equipment during flying in order to maintain safety and security in the aircraft during flying.

The writer believes, if there are passengers who use electronic equipment intentionally cause interference with telecommunications signals and interfere with flight navigation signals, the passenger will violate the provisions of clause 54 Letter a because it threatens the safety and security of aircraft in flight. This is because, in the provisions of constitution Number 36, 1999 concerning Telecommunications, it also regulates the prohibition of the use of telecommunications that interfere with each other. Particularly those governing the prohibition of interference with telecommunication equipment of radio frequency spectrum and satellite orbit are clearly stated in clause 33 Paragraph (2) and clause 38.

Clause 33 Paragraph (2) states that: "The use of radio frequency spectrum and satellite orbit must be in accordance with its purpose and not interfere with each other," while Clause 38 states that: "Everyone is prohibited from carrying out acts that can cause physical and electromagnetic interference to telecommunications operations. "This relates to Clause 54 letter $\mathrm{f}$ which prohibits the operation of electronic equipment that can interfere with flight navigation. So that passengers on board are required to deactivate their electronic equipment and if they use it must be wisely and in accordance with their objectives. In the explanation section of Clause 54 of constitution Number 1, 2009 concerning Aviation, the explanation of Clause 54 only provides a statement that the clause is clear enough. The writer believes that in the explanation section, further clarification is needed that can provide legal certainty especially in Clause 54 letter $\mathrm{f}$. The required explanation can be related to procedures and / or mechanisms for the use of electronic equipment in the aircraft which are feared to interfere with aircraft flight navigation such as the requirement to activate the airplane mode feature to prevent interference with flight navigation signals and aircraft communication devices, so the clause explanation does not provide definite clarity this becomes a loophole for anyone to activate their electronic equipment inside the aircraft during flying by arguing that their laptops or cellphones do not cause dangerous signals to the flight navigation system. The final attempt can only be made by cabin crew or flight attendants / stewards to reprimand and / or order to deactivate electronic equipment that is being used by passengers.

this unclear and uncertainty was finally utilized by the airline PT Citilink Indonesia to follow its parent company PT Garuda Indonesia (Persero) Tbk, to present Wi-Fi Onboard with Free Wi-Fi facilities on board without violating clause 54 letter $f$ or any of the clause contained in regulations of constitution Number 1, 2009 concerning Aviation. This is in accordance with clause 30 paragraph (1) letter e Regulation of the Minister of Transportation Number PM 185, 2015 concerning Passenger Service Classes of Domestic Scheduled Commercial Air Transport (PM 185/2015), stating that: "Air transport business entities must provide entertainment media ", Then airlines with full service groups must provide entertainment media. As a form of additional service to passengers in the form of providing entertainment media on board, in addition to providing In-Flight Entertainment (IFE) in each passenger seat.

Interviewed with Melia Prabangasta Yustisia

Onboard Wi-Fi was first present on Garuda Indonesia aircraft, so Garuda conducted an assessment both in terms of safety and security regarding the provision of Wi-Fi Onboard, including coordinating with the Ministry of Transportation regarding whether the Wi-Fi Onboard service is safe to run. The results of the assessment of safety and security aspects have been carried out by Garuda Indonesia and in coordination with the Ministry of Transportation, the intended Onboard Wi-Fi service is not a prohibited activity based on clause 54 Letter $\mathrm{f}$ of constitution Number 1, 2009 concerning Aviation

(Interviewed with Melia Prabangasta Yustisia).

Therefore, according to the writer, there are laws and regulations that need to be updated, Constitution No. 1, 2009 concerning Aviation which is considered to be incompatible with the development of times regarding safety and security in the operation of electronic equipment on aircraft; by following the rapid development of communication and information technology advancements. Therefore, attention and role from Government agencies are needed to review the clause in constitution Number 1, 2009, concerning Aviation, which article needs to be updated because it is out of date for the realization of legal certainty in Indonesia. 
Based on the writer's analysis, the presence of WiFi OnBoard with Free Wi-Fi facility connected to electronic equipment on the aircraft of Citilink Indonesia is classified as safe and does not violate the provisions of Article 54 Letter $\mathrm{f}$, if supported by the use of airplane mode or the so-called airplane mode on electronic devices. This is according to the results of an interview with Melia Prabangasta Yustisia as the Legal Advisor Regulatory, Compliance \& Quality Assurance Unit of the Corporate Legal \& Compliance of PT Garuda Indonesia (Persero) Tbk, which said that when the sign to use a seat belt had been extinguished, at altitudes above 30,000 feet of passengers only allowed to activate electronic equipment to access wi-fi facilities, passengers are required to activate the airplane mode on the electronic device first. Interview with Melia Prabangasta Yustisia. Where passengers can simply change the signal mode of the gadget or electronic equipment to airplane mode to be able to connect with Wi-Fi contained in the aircraft, the passenger can enjoy the Free Wi-Fi facility to access social media or watch movies, and others. With the support of modern WiFi OnBoard technology, the signal will be reflected through satellites located in the air and not passing through telecommunications poles or telecommunications towers located on land. So the operation of electronic equipment when connected to $\mathrm{WiFi}$ OnBoard is considered not to cause dangerous signals and signals that interfere with the flight navigation system.

Based on the writer's analysis, the presence of Wi-Fi on-board with Free Wi-Fi facility connected to electronic equipment on the aircraft of Citilink Indonesia is classified as safe and does not violate the provisions of clause 54 Letter $\mathrm{f}$, if supported by the use of airplane mode on electronic devices. . This is in accordance with the results of an interview with Melia Prabangasta Yustisia as the Legal Advisory Regulatory, Compliance \& Quality Assurance Unit of the Corporate Legal \& Compliance of PT Garuda Indonesia (Persero) Tbk, which said that when the sign to use a seat belt was extinguished, at an altitude above 30,000 feet, passengers are allowed to activate their electronic equipment to access Wi-Fi facilities, passengers are required to activate the airplane mode in their electronic devices first. Interviewed with Melia Prabangasta Yustisia. Where passengers can simply change the signal mode of the gadget or electronic equipment to airplane mode to be able to connect with Wi-Fi contained in the aircraft, the passenger can enjoy the Free Wi-Fi facility to access social media or watch movies, and others. With the support of modern Wi-Fi on-board technology, the signal will be reflected through satellites located in the air and not passing through telecommunications poles or telecommunications towers located on ground. So the operation of electronic equipment when connected to WiFi on-board is considered not to cause dangerous signals and signals that interfere with the flight navigation system.

\subsection{Safety and Security in Flight}

Airplanes are actually the safest means of transportation in the world. Airplanes are made with very strict requirements. All critical parts, which greatly affect the safety and security of aviation are designed in such a way that the possibility of a failure in a function in 10 flights only occurs 1 time a failure, but there are other factors that play a role in the safety and security in flight. The condition of an aircraft itself is not a guarantee of safety. Other factors include weather, pilot error, abandonment of procedures, and community culture. Pilot error in controlling the aircraft and the error of passengers who do not do things as they should is one of the most influential factors on safety and security in flight, it can be mentioned that the human error factor is considered as the most influential factor in aviation accidents.

Asro Nasiri, Tohir Ismail, "Visualization of Aircraft Navigation in a Three Dimensional Format". Dasi Journal, Vol. 11 No. 1 (March 2010), pp.56-65.

Based on clause 1 number 48 constitution No. 1, 2009 concerning Aviation, "Aviation Safety is a state of fulfilling safety requirements in the use of airspace, aircraft, airports, air transportation, flight navigation, and supporting facilities and other public facilities," while Based on clause 1 number 49 of constitution No. 1, 2009 concerning Aviation, "Aviation Security is a condition that provides protection to airlines from unlawful actions through the integrated use of human resources, facilities, and procedures."

The Meaning of navigation according to the Indonesian Big Dictionary (KBBI) is a science of how to run a ship or an aircraft by the act of placing the bow of the ship or the direction of flight where the plane crash was caused by navigation errors then one of the elements of aviation safety requires good navigation facilities. Whereas based on clause 1 number 46 of constitution Number 1, 2009 concerning Aviation states that the meaning: "Flight navigation is the process of directing aircraft motion from one point to another safely and smoothly to avoid flight hazards and / or obstacles." 
Flight navigation works to determine the direction of the plane and control the height of the plane on ground or over the sea. Flight navigation can be exemplified as a system of directions for pilots so that the plane does not go out of its way so that it can arrive at its destination according to the location and time specified. Flight navigation works by using a radio channel to communicate between the pilot and the Air Traffic Controller (ATC) tower. Aviation navigation equipment connected to radio waves consists of:

1. Radio Magnetic Indicator / Radio Directional Finder (RMI / RDF), determine the position of the aircraft's destination by receiving radio signals in the form of VHF Omnidirectional Radio Range (VOR) waves.

2. Course Deviation Indicator (CDI), determine the position of the aircraft's destination by receiving radio signals in the form of VHF Omnidirectional Radio Range (VOR) waves.

3. Radio / Radar Altimeter (RA), a tool for measuring aircraft altitude.

Interviewed with Faqih Rezka

So that the safety and smoothly in flight are also affected by navigation of a flight that runs well without any technical interference that is made or not made intentionally that can cause danger in flight. In order to create a good and smooth flight navigation system, navigation observer assistance is needed as one of the supporting infrastructure for airport operations. Flight navigation observers will be at the flight destination location which is often known as the Air Traffic Controller (ATC) tower. With the flight navigation observer can make the flight process easier in maintaining the status of the aircraft's direction and related to the condition of the aircraft when in the air, so that pilots can easily communicate in the air to determine the direction of their destination and aircraft status. Therefore, it is necessary to have radio channels and communication channels that are smooth and free from interference in every flight.

Aviation navigation equipment and communication equipment between pilots and the Air Traffic Controller (ATC) tower can be disrupted if there are passengers who activate their electronic devices inside the aircraft while in the air. This is because electronic devices, especially mobile phones, even though they are above the sky with a height of 30,000 feet, will continue to do everything in their power to search for signals emitted by telecommunications towers on land. Although there is also an airplane mode feature, it is recommended that all activities be carried out after arriving at the destination. Therefore, electronic devices must remain disabled so as to prevent disruption of navigation and communication devices.

Interviewed with Faqih Rezka

The rapid development of information and communication technology has entered air transportation services. The development of this technology is marked by the emergence of a communication network that uses electronic media called the internet. The internet has been redeveloped in communication and information technology to produce a technology that has the term Wireless Fidelity (Wi-Fi). Wireless (wireless network) is a communication network between computers using radio frequencies. The development of the use of Wi-Fi technology has grown so rapidly because access and transactions through the internet have become something very important, so that information and communication from the internet is one of the basic human needs that must be met.

The development of communication and information technology brings its own changes, especially in aviation. Indonesian airlines take advantage of the increasingly modern development of information and communication technology by bringing Wi-Fi on-board for domestic routes. Although this is still considered a taboo due to the constitution No. 1, 2009 concerning Aviation in particular clause 54 Letter $\mathrm{f}$ which states that it is prohibited to use electronic devices in aircraft which can interfere with flight navigation.

The write's opinion, if a passenger activates his electronic devices on a plane to connect it to the Free WiFi facility, then the Wi-Fi on-board technology by Citilink airlines service from the provider uses connectivity via satellite waves can be classified as safe for flight navigation and communication. This is also due to the absence of signal collisions or signal overlap because Wi-Fi on-board uses satellites whose radio waves will not be in the same path with radio waves from telecommunications towers on ground. The satellite method will have a more stable and stronger connection because the Wi-Fi signal received by the aircraft is obtained from satellites that are in outer space. So there is no limit when passing through the ocean or mountains because the satellites are on the plane.

According to the writer, there is a difference of opinion between the first and second sources, where the first source said that the use of electronic equipment that connects with Wi-Fi on the plane is safe and does not interfere with following the procedures recommended by the airline that electronic equipment can be activated after the seat belt sign is extinguished and the aircraft is above 30,000 feet and activates the airplane mode 
feature on every electronic device operated. (Interviewed with Melia Prabangasta Yustisia). This aims to create good and smooth flight navigation and aircraft communication tools without interference so that safety and security aspects of flight are maintained. Whereas the second informant said that it was not allowed to activate electronic equipment inside the aircraft because the signal generated by electronic equipment could interfere with the navigation and pilot communication signals with the Air Traffic Controller (ATC) tower, because even though it was above the sky and had the airplane mode feature, the operation of electronic equipment is recommended after arriving at the destination. (Faqih Rezka) It also aims to create good and smooth flight navigation and aircraft communication tools without any disruption so that safety and security aspects of flight are met.

Based on the writer's analysis, the presence of free Wi-Fi facilities in Citilink airlines has led to pros and cons in the community, because it is generally known that airplanes are prohibited from activating electronic equipment which is feared to cause interference with the navigation signals and disrupt the flight path. communication and threatening safety and security in flight, but with the Garuda Indonesia Group conducting an internal assessment regarding the safety and security aspects of the installation of Wi-Fi Onboard and Garuda Indonesia Group coordinating with the Ministry of Transportation regarding the presence of Wi-Fi services, the Wi-Fi Onboard is said to be able to run and does not interfere with performance flight navigation system so that safety and security are maintained. Interviewed with Melia Prabangasta Yustisia.

So the Wi-Fi on-board technology used by Citilink airlines with satellite wireless network services, will not interfere with the in-flight flight navigation system. So that flight navigation tools such as VHF Omnidirectional Range (VOR), Radio Directional Finder (RDF), Course Deviation Indicator (CDI), Radio / Radar Altimeter (RA), Instrument Landing System (ILS), Global Positioning System (GPS), and tools communication with Air Traffic Control (ATC) can run well and smoothly without any interference from the signals generated by $\mathrm{Wi}-\mathrm{Fi}$ users on the plane. So the pilot can control the aircraft well and pay close attention to flight navigation instruments and communication with the Air Traffic Control (ATC) tower that uses radio channels will be free from any unexpected signal interference that can cause Lost Contact.

The presence of $\mathrm{Wi}-\mathrm{Fi}$ on-board as an additional service facility provides its own comfort for its passengers by playing gadgets on the plane without worrying about the signal from his device disrupting flight navigation and pilot radio frequencies with the Air Traffic Controller (ATC) tower, because flight navigation and communication devices can still working fully well to determine the direction of the destination and adjust the height of the aircraft when flying.

The application of Wi-Fi on-board is also in accordance with constitution Number 36, 1999 concerning Telecommunications because it is based on clause 33 Paragraph (2) which states that "The use of radio frequency spectrum and satellite orbit must be in accordance with its designation and not interfere with each other." The passengers who activate their gadget and connect to Wi-Fi on-board will not violate this article because the signal captured by the aircraft from the satellite will not interfere with the flight navigation signal and radio frequency communication equipment contained in the aircraft.

\section{Conclusion}

Based on the description of the main problems raised, the conclusions are as follows: The policy of providing free Wi-Fi facilities on the aircraft does not conflict with clause 54 letter $\mathrm{f}$ of constitution No. 1, 2009 , because Wi-Fi on-board technology is different from Wi-Fi technology found on land. Onboard Wi-Fi is connected to satellites in the sky and when passengers activate their electronic equipment on board to enjoy these facilities it does not have bad consequences and makes flight operations unsafe if supported by using airplane mode or the so-called airplane mode feature on electronic devices.

The existence of Wi-Fi on board still guarantees and maintains safety as well as security in flight. The implementation of the free Wi-Fi policy by airlines on the operation of flights does not have a negative impact resulting in the non-operation of the flight navigation system as a result of the implementation of the free $\mathrm{Wi}-\mathrm{Fi}$ policy by the airlines on flight operations. Flight navigation works to determine the direction of the plane and control the height of the plane on ground or over the sea. Flight navigation works by using a radio channel to communicate between the pilot and the Air Traffic Controller (ATC) tower. The presence of Wi-Fi on-board provides comfort for passengers by feeling the sensation of playing gadgets on the plane.

The impact of Wi-Fi Onboard strongly supports passenger comfort facilities on its journey and the airlines have examined in-depth internal assessments regarding the safety and security aspects of Wi-Fi Onboard installation and coordinated with the Ministry of Transportation regarding the presence of Wi-Fi services, so 
Wi-Fi Onboard is said to be able to run and does not interfere with the performance of the navigation system flight so that safety and security are maintained. The application of Wi-Fi On Board is also in accordance with the provisions of constitution Number 36 of 1999 concerning Telecommunications clause 33 Paragraph (2). Based on this clause, passengers who activate their gadget and connect to Wi-Fi on-board will not violate this article because the signal captured by the aircraft from the satellite will not interfere with the flight navigation signal and radio frequency communication equipment contained in the aircraft.

\section{References}

[1] Abdulkadir Muhammad, Commercial Transportation Law, (Bandung: Citra Aditya Bakti, 2008), p. 189

[2] H.M.N Purwosutjipto, Basic Understanding of Indonesian Commercial Law Volume 3, (Jakarta: Djambat, 1991)

[3] Soerjono Soekanto, Introduction to Law Studies, (Depok: UI-Press, 2010)

[4] T. Kansil, et al, Introduction Law Studies and Indonesian Law, (Jakarta: Balai Pustaka Publisher, 2008)

[5] Asro Nasiri, Tohir Ismail, "Visualization of Aircraft Navigation in a Three Dimensional Format". Dasi Journal, Vol. 11 No. 1 (March 2010), pp.56-65.

[6] Rio Priantama, "The Effectiveness of Wi-Fi in Supporting the Education Process for Higher Education Institutions". Cloud Information Journal, Vol. 1 No. 1, h. $22-28$.

[7] Prize Titahningsih, Rakhmadhany Primananda, Sabriansyah Rizqika Akbar, "Designing Access Point Placement for Wifi Networks on Passenger Trains". Journal of Information Technology and Computer Science Development, Vol. 2 No. 5 (May 2018), pp.2008-2015.

[8] Aflah and Zulfi Chairi, "Responsibility of Air Navigation in Air Traffic Services for Flight Safety". Journal of the Ministry of Law, Volume 29, No.1 (2017), p.1-15.

[9] Asro Nasiri, Tohir Ismail, "Visualization of Aircraft Navigation in a Three Dimensional Format". Dasi Journal, Vol. 11 No. 1 (March 2010), pp.56-65.

[10] History of Wi-Fi on Airplanes "(On-Line), available at: https://www.garuda-indonesia.com/en/gar/garuda-indonesia-experience/in-flight/connectivity/index.page? (July 10, 2019)

[11] Wifi on Batik Air planes", (On-Line), available at: https://makassar.tribunnews.com/2013/04/10/facility-wifi-di-batik-air (July 16, 2019)

[12] AirAsia Wifi "(On-Line), available at: https://www.airasia.com/en/id/press-releases/airasia-indonesia-l Launch-services-Wi-Fi-in-flying-first-highways-first- at-indonesia.page (July 16, 2019)

[13] Free Wi-Fi Citilink "(On-line), Loc.Cit.,Air Navigation ", (On-line), available at http://k gather-jurnaldunia-q.andrafarm.com/id1/2906-2783/Navigate Air_196460_category-world-journal-qandrafarm.html (May 27, 2019)

[14] Wi-Fi on-board ", (On-Line), available at: https://www.tiket2.com/blog/how-the -work-of-Wi-Fi-onboard/ (July 24, 2019)

[15] Flight Comfort "(On-Line), available at: http://ergo.human.cornell.edu/dea3250flipbook/dea3250notes/sitting.html. (May 29, 2019)

[16] Wi-Fi Onboard ", (On-line), available at https://phinemo.com/wifi-onboard-citilink/ (May 30, 2019)

[17] Wi-Fi On-board", (On-line), available at https://www.tiket2.com/blog/ini-dia-15-support-that-providesaccess-wifi-on-board/ (31 May 2019 )

[18] Free Wi-Fi Citilink ", (On-Line), available at https://travel.detik.com/travelnews/d4301617/garudaindonesiagruplfreewifidio on airplanes? $\quad \mathrm{ga}=2.190102379$ $1134469091.1551691090-1210504586.1551691090$ (June 10201201 )

[19] Empirical and Normative Legal Research ", (On-Line), available at https://idtesis.com/method-studyinvestment-empiri- and-normative (21 March 2019)

[20] Domestic Flights "(On-Line), available at: http://wordnetweb.princeton.edu/ perl / webwn? O2 = \& o0 $=1 \& 07=\& 05=\& 01=1 \& 06=\& 04=\& 03=\& 0=$ domestic + flight $\& \mathrm{i}=0 \& \mathrm{~h}=0 \# \mathrm{c}$ (April $18,2019)$

[21] International Flights "(On-Line), available at: http: //wordnetweb.princeton. edu / perl / webwn? s = international + flight \& sub $=$ Search + WordNet \& $02=\& 00=1 \& 08=1 \& 01=1 \& 07=\& 05=\&$ $\mathrm{o} 9=\& \mathrm{o} 6=\& \mathrm{o} 3=\& \mathrm{o} 4=\& \mathrm{~h}=100(18$ April 2019).

[22] Internet "(On-Line), available at: https://www.internetsociety.org/internet/history-internet/brief-historyinternet/ (21 April 2019).

[23] Qualitative Approach ", (On-line), available at: http://www.academia.edu/13286586/ (March 22, 2019) 
[24] Flight Navigation ", (on-line), available at: https: // flyawaysimulation. com / knowledge / (April 21, 2019)

[25] Wi-fi ", (On-line), available at: https://www.webopedia.com/TERM/W/Wi_Fi.html (21 April 2019)

[26] WLAN ", (On-line), available at: http://www.pengahamanku.net/2015/01/pengahaman-wlan-atauwireless-lan.html (21 April 2019) 